\title{
THE ART OF THAUMA: NATURE, ARTIFICE AND THE MARVELLOUS
}

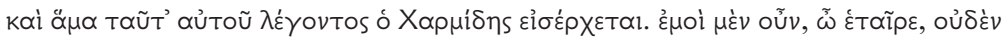

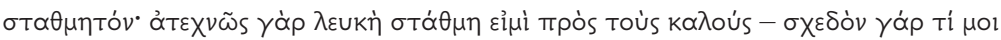

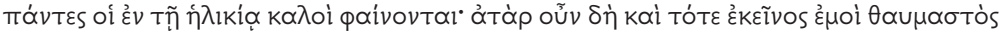

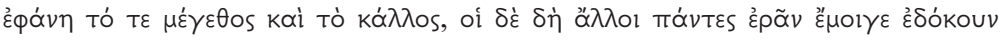

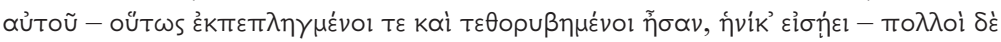

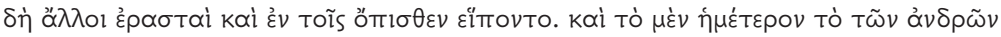

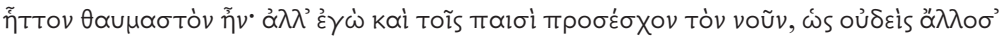

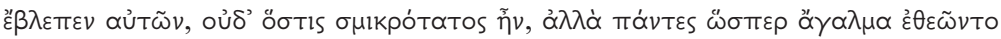

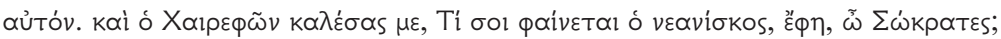

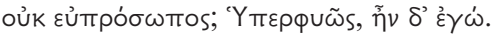

Plato, Charmides I 54b-d

And as he was saying this, in comes Charmides. Now I, my friend, am no judge. I am simply a 'white line' when it comes to beautiful people. ${ }^{\text {I }}$ For almost all lads at that time of life seem beautiful to me. But right at that moment that boy seemed to me to be a marvel both in terms of his size and his beauty, and everyone else seemed to be in love with him, since they were so astonished and bewildered when he entered. And many other lovers trailed in his wake. Now our behaviour - that's to say that of the older men - is no wonder. But I was paying attention to the boys as well, and none of them looked elsewhere, not even the smallest, but everyone gazed at him as if he were a statue (agalma). And Chaerephon called me over and said: 'How do you like the young man, Socrates? Is he not good looking on the outside?' 'Preternaturally so,' I said.

The importance of thauma as a term of aesthetic response to the visual arts in the Classical period has recently been explored in Richard Neer's study of the effects of Archaic and Classical sculpture, which suggests that the pursuit of thauma increasingly drives artistic innovation over the course of the Classical and into

I A common proverb which seems to mean something like 'I am unable to judge correctly', 'I am indiscriminate'. As explained at $\Sigma$ ad. Chrm. I 54b, the imagery is from the realm of building and architecture: a white chalk line used as a straight rule is not distinguishable if the stone or marble being cut is itself white. 
the Hellenistic period. ${ }^{2}$ But thauma is not only a key term in relation to visual art. It is also a response which eventually comes to be associated with the effects of written texts on their readers. Over the course of the Classical period and into the Hellenistic age, the written text itself becomes the most powerful example of what a thauma is and does. In this chapter, I will begin to examine certain aspects of the relationship between the visual, the verbal and the textual which are explicitly shown to elicit wonder from very early on in the Greek literary tradition, particularly in passages of ekphrasis, before moving on to explore the relationship between text and thauma more fully in the next chapter, taking Hellenistic paradoxographical collections as my primary examples. But before exploring these issues fully, it is first worth turning to the image of the beautiful young Charmides as a wondrous agalma at the opening of the Platonic dialogue which bears his name to introduce some of the main themes of the forthcoming discussion.

In many of Plato's works, the framing scenes or opening details of the narrative foreshadow the eventual philosophical outcome of the dialogue. ${ }^{3}$ Charmides is no exception to this tendency: the sense of wonder which surrounds the young man on his entrance into the palaestra of Taureas will go on to colour our response as the dialogue draws on. Charmides' wondrous effect on the assembled company in this scene is explicitly caused by his beautiful appearance. The astonishment this beauty causes in his viewers is in fact so great that it is akin to the kind of aesthetic response provoked by artworks. There is something uncanny about Charmides in Socrates' description here - he is a moving, living man compared to a perfectly formed, static, inanimate statue: an agalma. This explicit comparison of a human being to an agalma from the point of view of the assembled company is somewhat

\footnotetext{
2 See especially Neer (20 IO) 20-IO3; cf. also Neer and Kurke (20I9) 59-6I on thauma and artworks.

3 For example, in relation to this dialogue, Reece (I998) shows how the erotic motifs in the opening of the Charmides are worked out in the text's later discussion of sophrosyne. Many other recent works have demonstrated the significance of the opening scenes of Platonic dialogues in relation to the later main philosophical discussion: cf. e.g. Clay (I992), Tschemplik (I993), Johnson (I998), Rudebusch (2002), Gonzalez (2003), Segvic (2006), Trivigno (20I I), Kaklamanou and Pavlou (20I6), De Sanctis (20I6).
} 


\section{I Wondrous Visions: Charmides as Agalma}

unusual. ${ }^{4}$ But the inversion of this comparison, the idea that an inanimate statue or artwork is actually in some sense 'alive', has a long history in Greek culture. ${ }^{5}$ In fact, the ability of an artwork or object of craft to move itself in some sense is an archetypal thauma from Homer onwards. What does Plato mean then by inverting this idea, comparing a young man to a marvellous artwork, and what is the significance of this gesture in the broader context of the Charmides? And what does Plato's use of the connection between visual artworks and wonder here tell us about the place of thauma in Greek literature and culture in this period?

\section{I Wondrous Visions: Charmides as Agalma}

As the passage quoted above in the epigraph demonstrates, the immediate response of the assembled company to Charmides' entrance into the palaestra is one of sheer astonishment. Even the young boys who are present are physically transfixed with amazement at the sight, while their minds too are 'astonished and

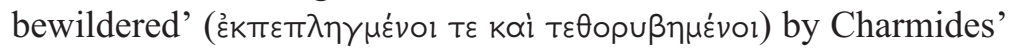
wondrous beauty upon his sudden, almost epiphanic arrival before them. The immediate, imposed fixity of the stunned audience, physically paralysed by eros, contrasts with Charmides' onrushing entrance - we might have expected the spectators to be described as statuesque, rather than Charmides himself. The way in which the beautiful young man's arrival suffuses the whole setting with wonder is emphasised even further by Socrates' pun on thauma

4 There is another prominent example of a living human being compared to an agalma while focalised through the eyes of another in Euripides' Hecuba when Talthybius describes how Polyxena bares her breasts and appears beautifully 'like an agalma' ( $\dot{s}$

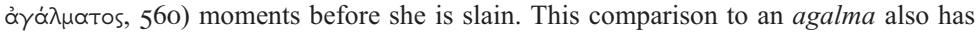
a distinctly erotic tinge, just as it does at the beginning of the Charmides: on this presacrificial erotic aestheticisation, see Scodel (I996) I I I-28; cf. Thalmann (I993) I43-8 and Steiner (2001) I97, 207 on the connection between eros and agalma in the Hecuba. Another striking aspect of this comparison is the fact that Polyxena is on the verge of death at this moment and is about to change from an animate to an inanimate being. The antithesis between animate/inanimate and living/dead is crucial to the perceived power of the agalma as an artwork: the simile is therefore especially apt at this point in the Hecuba since it reflects Polyxena's transitional state as she approaches her inevitable end.

5 See Spivey (1997) 442-59, Steiner (200I), Hersey (2009) and Neer (20I0) on the ancient idea of animated statues; see also Faraone (I987) I 8-2 I on Hephaestus as the animator of statues, and Morris (I992) 2 I5-37 on Daedalus as the creator of animated statues. 
when he describes the older spectators' astonishment at the sight

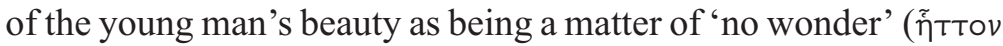
$\theta \alpha u \mu \alpha \sigma \tau o \dot{v} v \tilde{\eta} v)$. On the one hand, this is a vaguely humorous repetition of thauma-language which picks up on the description of Charmides' marvellous physical qualities to make a joke at the expense of the older males in the dialogue, who are portrayed as predictably and unsurprisingly reacting to the erotic charms of a younger man - nothing to wonder at in that type of response, Socrates knowingly assures us. But at the same time, this pun keeps what is and is not a cause of wonder foremost in our minds as we reach the unexpected climax of the whole description: the comparison of the young man's form to that of a statue. Most surprisingly, this description suddenly collapses the boundaries between the animate and the inanimate: are the viewers here simply lusting after a young man, or a work of art?

The choice of the word agalma here increases the sense that the visual effect of Charmides' entrance is truly marvellous. In fact, there might even be a further boundary being blurred here - that between mortal and god. The word agalma suggests that the statue in question is a depiction of a god rather than that of a man and hints that the representation is a special cause of delight. ${ }^{6}$ The wondrous effect of his appearance can even be seen as a sort of pseudo-divine epiphany. ${ }^{7}$ The very boundaries between gods and men, and inanimate and animate objects, are seemingly challenged by the young man's marvellous beauty. ${ }^{8}$ Indeed, Socrates picks up

${ }^{6}$ Other words for statues, such as ảvoplós, are much more common for depictions of mortals (especially real-life mortals rather than mythical figures). Platt (20 I I) 90 sums up the wondrous effect which the connection of agalmata to the divine sphere tends to produce: 'the agalma projected a glorious radiance that pertained to the immortal sphere, but was also closely bound to the material significance of precious objects, simultaneously encompassing the notion of things mysteriously alive and the splendid, "thaumastic" effects of superior craftsmanship'.

7 Steiner (200I) I30: 'the youth's advent and appearance have all the qualities of a divine epiphany'. Cf. Platt (20II) 56: 'In the vocabulary of archaic Greek experience, an epiphany functions as the ultimate form of thauma.

8 The use of the word agalma in instances involving overwhelming beauty and/or overwhelming eros which blurs the boundaries between mortal and divine is found elsewhere in Plato's work, most notably at $P h d r .252 \mathrm{~d}$, where a lover is said to treat his beautiful beloved 'as if he were his god, he crafts him and adorns him, like an agalma'

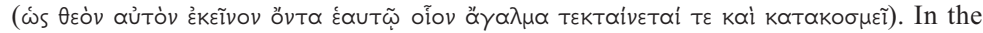
Symposium Alcibiades plays with similar imagery three times in his speech in praise of Socrates, first when he compares the older man to a statue of Silenus containing 


\section{I Wondrous Visions: Charmides as Agalma}

on this sense that Charmides' physique somehow goes 'beyond the bounds' of what is natural in his response to Chaerephon when he affirms that the young man is indeed 'exceedingly'

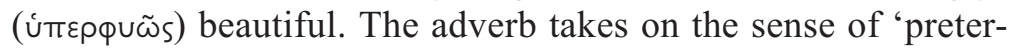
naturally' here in conjunction with the use of agalma; the idea is that this is not a normal, human sort of beauty. ${ }^{9}$ There is, however, a certain ambivalence inherent in this description. The use of agalma hints that Charmides' looks are worthy of the gods themselves. In the Classical period, the surface appearance of a sculpture becomes particularly important in creating a dazzling thaumatic effect, and Charmides is certainly able to do that. ${ }^{\text {IO }}$ But, on the other hand, a potential superficiality and hollowness are also being hinted at here. Is Charmides all surface dazzle and hollow within, just as a statue is? Or is he beautiful on the inside as well as on the surface?

We know that the possible content of the interior spaces of statues fascinated the Greeks. ${ }^{\text {II }}$ The issue of what is inside the agalma-like Charmides soon becomes a similar object of fascination to Socrates and his friend Chaerephon. Immediately after the young man's entrance, Chaerephon tells Socrates (I54d) that Charmides' current clothed form pales in comparison with his

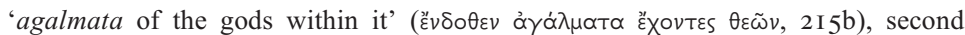
when he claims that 'the agalmata inside ... are godlike and golden and utterly

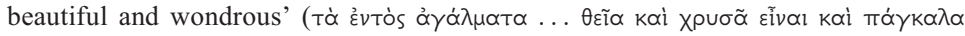

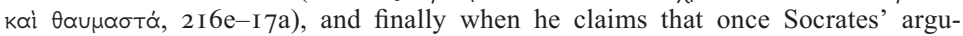

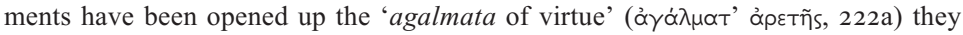
contain can be seen by everyone. As well as containing and producing wondrous agalmata Socrates is also said to elicit wonder in his listeners through his speech

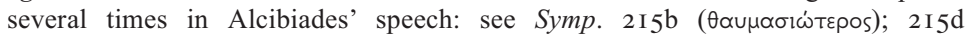

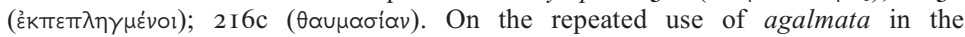
Symposium, see Reeve (2006) I $24-46$.

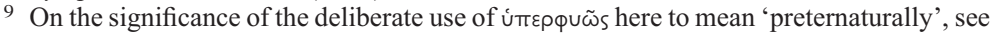
McAvoy (I996) 73. Cf. Reece (I998) 66 on Charmides' seemingly beyond-human beauty and Power (20II) 85 on the 'praeternatural valency' of Charmides as a superhumanly beautiful thauma which occupies 'an ontologically intermediate position between divine and human'.

Io See especially Neer (20IO) I42 ff. Cf. Stewart (I990) 40 on this point: 'A perfect finish attracts a customer or delights a god: the work becomes a "wonder" (thauma), one of the most powerful terms of commendation in the Greek language.'

${ }^{I I}$ See Steiner (200I) 79-I34; cf. Neer (20I0) I24: 'Classical drapery insists that there is something beneath the carved surface'; see also I $42 \mathrm{ff}$. on the importance of drapery for the creation of the suggestion that statues have some sort of interior life; cf. Neer and Kurke (20I9) 60 on thauma and lifelike effects in artworks. 
naked body: his beautiful face would be an object of no interest whatsoever if only he would strip his clothes off and reveal his astonishing physique. But Socrates wants to strip Charmides down even further. He is not so much concerned with what lies beneath Charmides' drapery, but with what lies within the young man him-

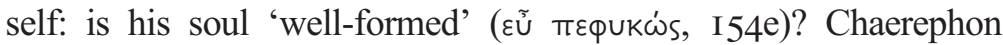
promises that Charmides is indeed just as well-made on the inside

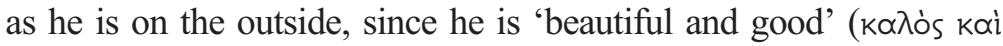
åy $\alpha$ ós, I 54e) in these respects too - but this remains to be tested. As a result, Socrates declares that he will now duly 'strip this (inside) part of him and have a look at it before looking at his external appearance'

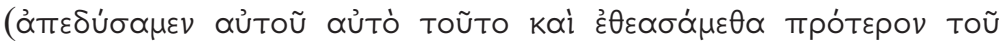

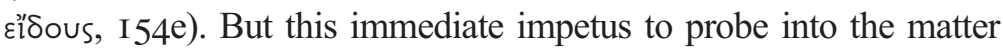
of Charmides' soul is almost entirely derailed when the young man approaches and Socrates discovers that he is even more beautiful than he had realised ( $55 \mathrm{c}-\mathrm{d})$. The play with inside and outside continues as Socrates accidentally catches a glimpse of what lies beneath Charmides' cloak when he sits next to him: totally overwhelming and paralysing eros is the result of this snatched sight of Charmides' wondrously beautiful naked body. ${ }^{\text {I2 }}$

There is an obvious playfulness to Socrates' reaction to Charmides throughout the opening of this dialogue. But, as so often with Platonic openings, the finer details of the Charmides' initial framing scenes do much to establish many of the main concerns of the subsequent discussion. In this case, the reaction of Socrates and his fellow spectators to Charmides' wondrous looks and agalma-like appearance is crucial in setting up the antithesis between surface appearance and inner morality and intellectual capacity which goes on to play an important role throughout the dialogue, as well as raising questions about the nature of the dialogue's central philosophical concept, sophrosyne (self-control), and its relation to wondrous and erotic sights. In addition to these specific themes, the thauma surrounding the quasi-epiphanic entrance of Charmides at the opening of this dialogue hints at the paradoxical double role which thauma more

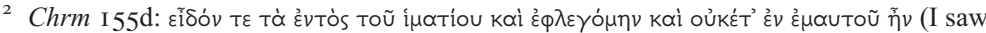
what was inside his cloak and I was inflamed and no longer in possession of myself). See McCabe (2007) I 2-I4 on the play with the idea of Charmides' inside and outside at the moment when Socrates catches sight of what lies beneath his cloak. 
generally plays in Plato's dialogues as both a possible spur to philosophical inquiry and a potentially dangerous (though often alluring) distraction.

\subsection{Plato's Marvellous Young Men: Theaetetus and Charmides as Thaumata}

It is helpful at this point to pause and think briefly about another Platonic young man who is also strongly associated with thaumatic effects of a very different sort. As he is presented in his eponymous dialogue, Theaetetus is in many respects the polar opposite of Charmides. Clever, brave and undoubtedly ugly, the young mathematician is explicitly figured as a youthful double of Socrates from the very opening scenes of the dialogue in terms of both his marvellous military bravery and obvious intellectual abilities. While the first image we get of Charmides is of stunning youth and beauty, in the Theaetetus the opening image of Socrates' interlocutor is Euclides' description to Terpsion of a youthful warrior cut off in his prime, 'grievously injured by his wounds and scarcely clinging on to life'

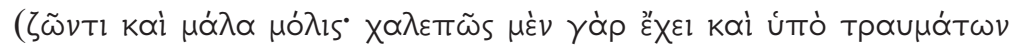

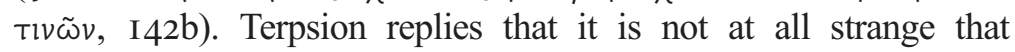
Theaetetus has been praised by others for his bravery in battle at Corinth; the only strange and potentially 'much more marvellous'

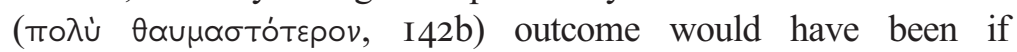
Theaetetus had not fought so bravely in battle, since he is the sort of man who habitually wins praise for his actions.

This opening description of Theaetetus' marvellous bravery is not without a purpose, for this is the first described aspect of his behaviour which recalls that of Socrates himself, whose own brave martial exploits were well-known. ${ }^{\mathrm{I} 3}$ These are mentioned at several points in Plato's dialogues, not least in the reference to Socrates' return to Athens (in May 429 BCE) after fighting at

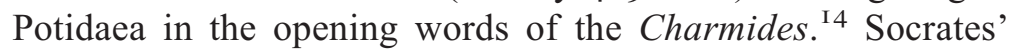
ability to withstand the rigours of campaign and fight bravely at

13 For an excellent overview of Socrates' military career and its depiction in Plato's dialogues, see Nails (2002) 264-5.

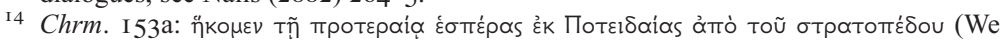
arrived yesterday evening from the camp at Potidaea). 
Potidaea also figures prominently in Alcibiades' repeated mentions of the 'marvellous' aspects of his behaviour in the Symposium. ${ }^{15}$ His bravery in the retreat from Delium $(424 \mathrm{BCE})$ is also mentioned both in that dialogue $(22 \mathrm{Ia}-\mathrm{c})$ and in the Laches (I8Ib), where Socrates' own brave conduct provides a starting point for the wider discussion of andreia (bravery) itself.

Theaetetus' military exploits will one day turn out to be equally impressive. But on Socrates' first meeting with the young man it is his intellectual qualities alone that elicit wonder. This becomes apparent before Socrates even meets Theaetetus in the flesh, when Theodorus praises the young man at length ( $143 \mathrm{e}-44 \mathrm{~b})$ :

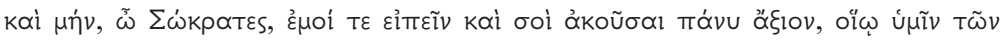

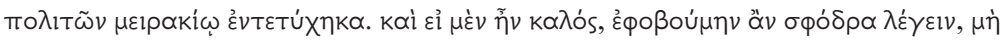

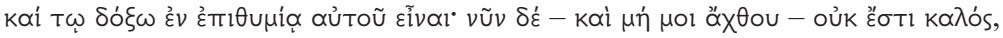

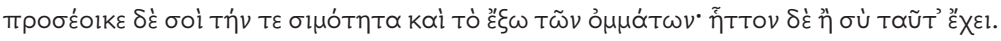

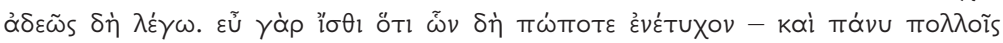

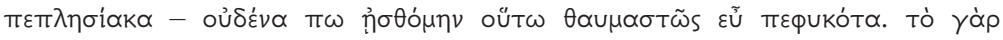

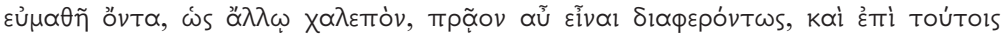

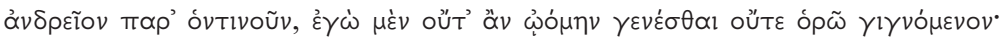

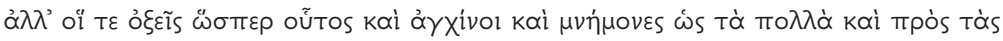

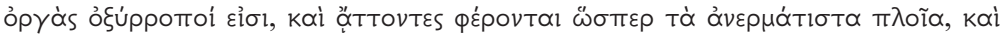

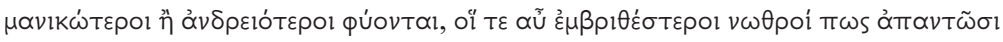

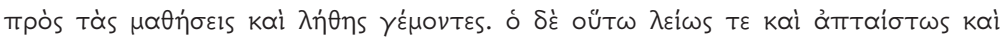

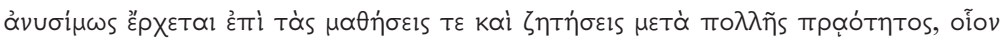

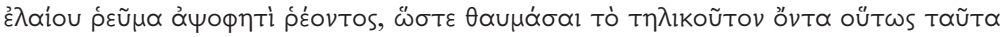

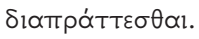

Well, Socrates, I think it's very worthy of me telling, and well worthy of you hearing, about a young man I have met with, one of your fellow citizens. And if he were beautiful, I would be very much afraid of speaking, in case I might seem to desire him. But as it is - and don't be aggrieved with me - he isn't beautiful, in fact he resembles you with his snub nose and protruding eyes (though these features are less pronounced in him than in you). Indeed, I speak fearlessly. Be assured that of all of those I have ever met - and I have associated with very many - I have never yet seen anyone so marvellously gifted by nature. He is quick to learn, beyond the capacity of other people, and unusually gentle, and on top of

15 E.g. at Symp. 220a-b, where Socrates' ability to withstand the cold while on campaign at

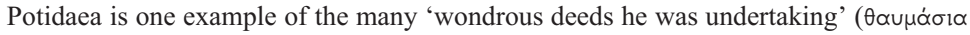

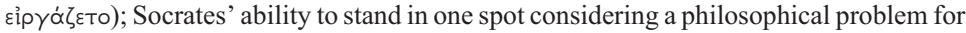
an entire day while on campaign was yet another thauma-inducing feat which caused

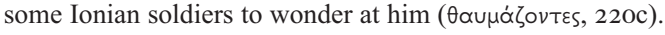




\subsection{Plato's Marvellous Young Men}

all this he is brave compared to any other. I would not have thought such a combination could exist, nor do I see it coming into existence. Instead, those who are sharp and shrewd and with good memories like him are usually quick to anger too, and darting off they are swept away just like ships without ballast, and they are more frenzied than courageous, and those who are steadier are somewhat dull in approaching their studies and are weighed down with forgetfulness. But this young man approaches his studies and inquiries with great gentleness, smoothly, without stumbling, and effectively, like a stream of oil flowing soundlessly, with the result that it is a marvel how he accomplishes these things at such an age as his.

According to Theodorus' high praise here, even the words of Theaetetus are as surprising and worthy of listening to as any marvel. Moreover, his uncanny physical resemblance to Socrates more than reiterates the point: this young man is a wonderful interlocutor in an intellectual sense, clearly cast as a sort of potential youthful double of Socrates himself.

The contrast with Charmides could not be starker. Theaetetus is certainly not an object of aesthetic thauma in the way that Charmides is, though wonder nevertheless plays a very important part in his characterisation. Out of all of Socrates' interlocutors, Theaetetus is the one who wonders most intently at the type of problems which occupy Socrates himself, as we see at Theaetetus I54c:

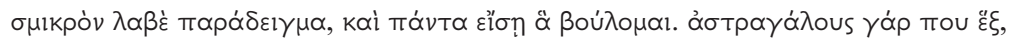

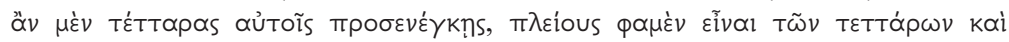

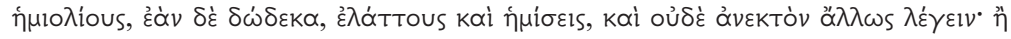

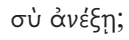

Take a small example, and you will know everything that I mean. There are, let's suppose, six knuckle-bones. If you place four beside them, we say that the six knuckle-bones are more than four - half as many more. But if you place twelve beside the six knuckle-bones, we say the six knuckle-bones are fewer - half as many fewer. And surely it's not acceptable to say this? Or will you accept it?

Theaetetus' immediate response to this mathematical problem reveals how intense his engagement with such problems is when he exclaims: 'By the gods, Socrates, I'm wondering excessively at the meaning of this: sometimes when I'm looking into these things

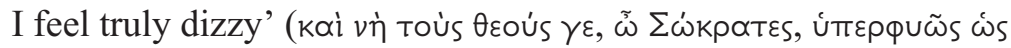

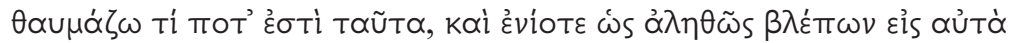




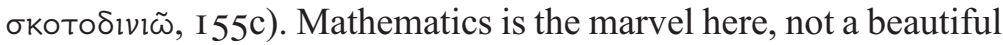
body or a sophistic display or a work of art, things which are the causes of a very different type of marvelling in Platonic dialogues. ${ }^{\text {I6 }}$ In fact, as Socrates himself goes on to tell Theaetetus, it is precisely the type of wonder he is feeling now

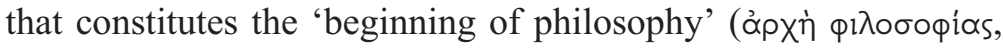
I55d) itself. ${ }^{\text {I }}$

For Charmides, in contrast, wonder as it exists for Socrates and Theaetetus - the wonder that leads to curiosity and cognitive advancement - is completely alien. In Plato's view, the amazement caused by real-world objects is a potentially dangerous, deceptive and cognitively paralysing state which must be avoided if possible, or handled carefully if not. Charmides himself presents a particular risk: he is a desirable object of wonder who physically embodies the distracting and stunning potential of marvelling at the objects of the phenomenal realm. The point of the emphasis placed on Charmides' appearance at the beginning of the dialogue thus becomes obvious enough as the work draws on: the young man is wondrously beautiful on the outside - but not much lies beneath.

\subsection{Critias the Poet, Charmides the Actor}

As it turns out, over the course of the Charmides it emerges that there is little intellectual material at all inside the dialogue's eponymous beautiful young man: like a bronze statue, his exterior causes him to become a delightful object of wonder, though he remains somehow hollow at the core. Once Socrates begins his customary elenctic questioning it does not take long for the suspicion that this might be the case to arise. Soon after the young man's grand entrance, Socrates embarks on a conversation with Charmides about the nature of sophrosyne. But Socrates' questions are not directed directly at Charmides alone for very long. His cousin and guardian Critias soon has to step in and take over the answerer's role once Charmides' initial ideas - that sophrosyne

${ }^{16}$ This latter form of Platonic marvelling will be more fully explored in Chapter 7.

17 On the significance of this saying in ancient philosophical thought, see also Llewelyn (I988) I73-9I. 
consists of 'doing everything in an orderly and calm fashion'

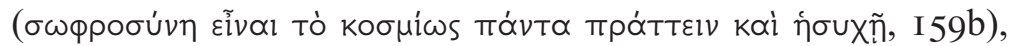
or that 'sophrosyne makes a man feel shame and modest, and that

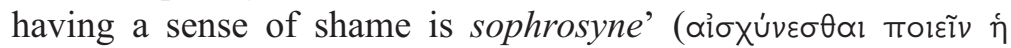

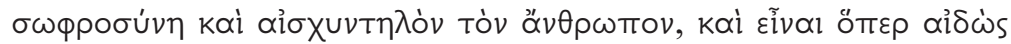

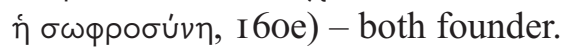

In fact, it soon turns out that Charmides' third definition of sophrosyne - that it is 'minding one's own business'

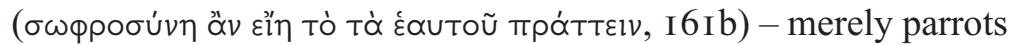
ideas which really belong to his cousin Critias. Socrates immediately suspects that this is the case, and after struggling to defend the proposition at any length Charmides, glancing significantly at Critias, confirms his suspicion. He excuses his own difficulties by claiming that the original author of the idea he has been advancing probably did not actually know what it meant either. ${ }^{\mathrm{I}}$ Critias' response to Charmides' move is telling ( $162 \mathrm{c}-\mathrm{d})$ :

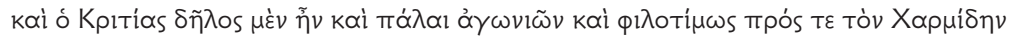

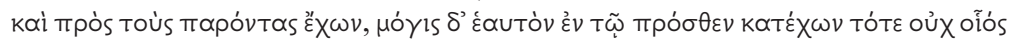

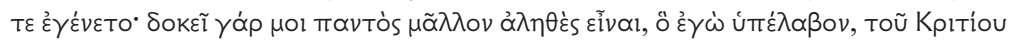

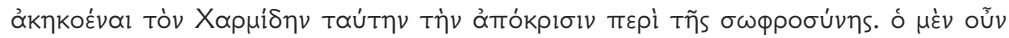

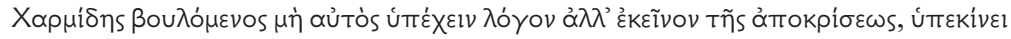

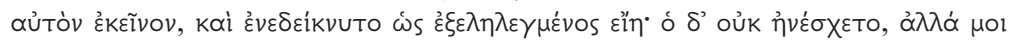

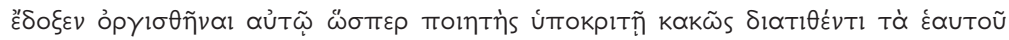

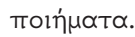

And it was clear that Critias had been distressed for a while and was eager for distinction in the eyes of Charmides and those present, and having scarcely restrained himself before, he was no longer then able at all. For it seems to me that what I had suspected before was completely true, that Charmides had heard his answer about sophrosyne from Critias. And so Charmides, since he did not want to play the answerer himself, began to nudge Critias towards it, and pointed out that he had been refuted. But Critias could not bear this, and seemed to me to be angry with him just as a poet is angry at an actor who recites his works badly.

Here a second simile is added to the earlier idea of Charmides as a wonder-inducing agalma. Charmides is now an actor, and Critias has become a poet. There is of course a joke here as well: Critias

${ }^{18}$ Chrm. I62b: $\alpha \lambda \lambda^{\prime}$ î

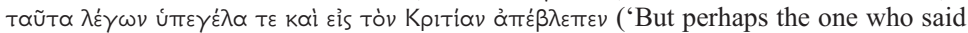
this did not know what he meant'. And at the same time as he said this he began to giggle and looked intently at Critias). 
was an extremely prolific writer and poet, known to have written hexameter and elegiac poems, tragedies and a satyr play, as well as numerous prose works of various sorts. ${ }^{19}$ What is most important here, however, is the sense that Critias has been providing Charmides with an intellectual 'script' by providing preprepared answers for the discussion with Socrates about the nature of sophrosyne. At this point in the dialogue, then, we have been introduced to two similes which indelibly colour our view of Charmides as a Socratic interlocutor. He is beautiful and provokes a paralysing sort of wonder, like an aesthetically beautiful agalma, and his intellectual performance has been compared to that of an actor performing someone else's text - at least up until the point here when he mischievously performs in a way which his director/ the author of the text he is performing (i.e. Critias) fails to anticipate.

How are these two images linked, and how do they relate to the wonder Charmides inspires in his viewers? One answer suggests itself by thinking about other instances in Plato where Socrates' implicit and humorous criticism of Charmides' reliance on Critias' ideas is echoed. One such place is the discussion of the advantages and disadvantages of using written texts at the end of the Phaedrus (274b-8e). Just as writing cannot spontaneously adapt itself in the moment to the (oral) questioner at hand since, being fixed, it

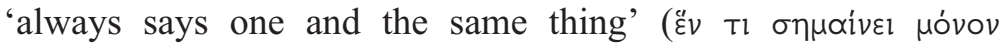
T๔ủTòv ởí, 275d) when someone questions it, leading to it always 'needing its father [i.e. the author] to come to its aid since it is

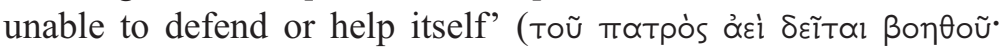

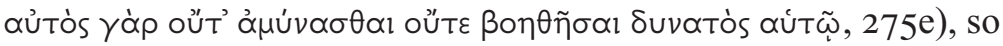
too Charmides is incapable of standing up to the rigours of Socratic questioning when advancing a Critian line. Just like a text, he soon needs his (literal) guardian to step in and take over. For Plato, the problem with both writing and with relying on the intellectual ideas of another without examining them for oneself is thus essentially the same: in both cases, the ideas being voiced belong to someone else.

I9 For an overview of Critias' literary career, see Nails (2002) I I O-I I. Solon was famously Critias' ancestor (see Chrm. I55a; Tim. 20e), and it is possible that he saw himself as a similar sort of statesman-poet: see Wilson (2003) I 87 on Critias' mimicry of Solon. 
In other philosophical and rhetorical works of the fourth century $\mathrm{BCE}$ the same sorts of problems are shown to occur even if the text happens to be one's own. Certain wonderful pre-planned rhetorical effects may be reliably wielded by a speaker, but the written text can never adapt effectively to new and unexpected arguments that are put to it in the cut and thrust of living debate. This is one of the reasons why Socrates had equated written texts with painted figures earlier on in the Phaedrus: figures in a painting may give the appearance of life, but they, like written texts, are unable to speak to the precise question put to them, remaining silent instead. ${ }^{20}$ As we shall see in the next section, this quality of seeming to be alive - the animation of inanimate material - is one of the qualities most strongly associated with the arousal of thauma. We see this problem outlined even more clearly in the thoughts of one of Plato's contemporaries, the rhetorician Alcidamas. In his treatise On Sophists, Alcidamas argues for the superiority of creating extemporised speeches rather than relying on pre-prepared written speeches, in terms which recall some of Socrates' arguments in the Phaedrus. ${ }^{2 \mathrm{I}}$ Alcidamas argues (On Sophists 27) that speeches written down beforehand are the 'images

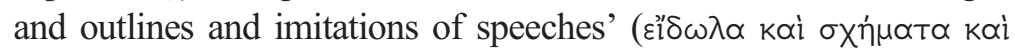
$\mu \imath \mu \eta \dot{\mu} \mu \tau \alpha \lambda \operatorname{\gamma og}(\omega \nu)$ made up on the spot, and we can think about them in the same way as we think about 'bronze statues and stone monu-

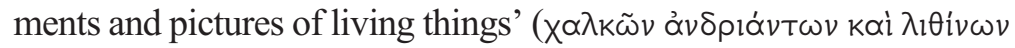

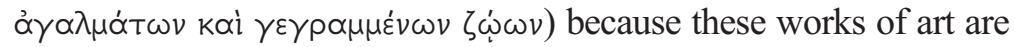
similar imitations of 'real bodies' ( $\alpha \lambda \eta \theta v v \tilde{\omega} v \sigma \omega \mu \alpha \dot{\alpha} \tau \omega \nu)$ which might

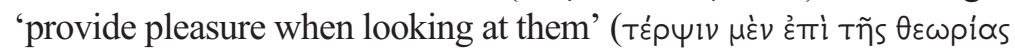

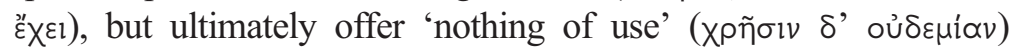
beyond that. ${ }^{22}$ He goes on to weigh up one of the advantages of

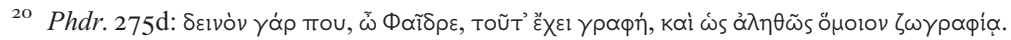

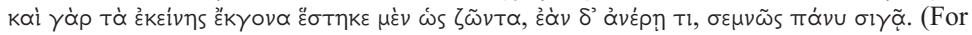
writing, Phaedrus, possesses this strange quality, and is truly like painting. For the figures of that art stand as if they are alive, but if you ask them anything, they remain solemnly maintaining complete silence). Plato is obviously drawing on and complicating an already well-established parallel between performed speech and artistic object here: cf. e.g. the opening of Pindar's Nemean 5 for the comparison of statue and song.

${ }^{21}$ On parallels between ideas in Plato's Phaedrus and those in Alcidamas' work, see O’Sullivan (I992) IOO-2.

22 On Alcidamas' use of this comparison between written speeches and the plastic arts in On Sophists, see Ford (2002) 233-5. 
using a written speech - the ability to deploy astonishing effects with the concomitant disadvantages of this approach (28):

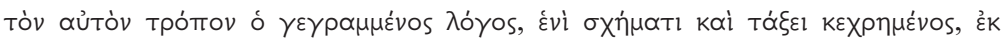

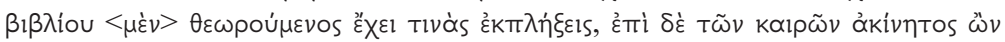

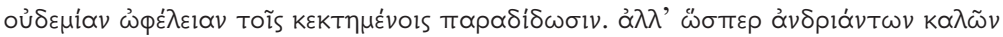

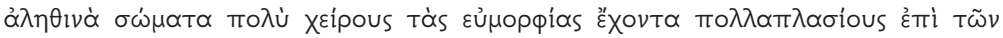

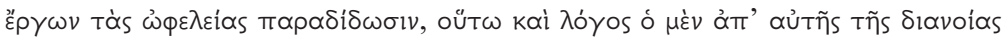

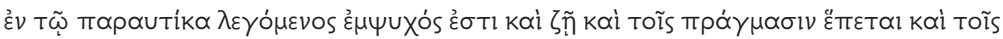

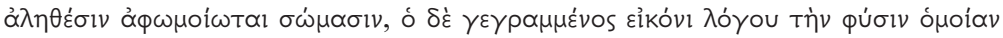

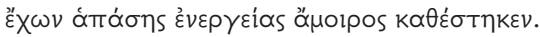

In the same way a written speech, which has one form and arrangement, has certain astonishing features when consulted from a book, but being incapable of movement at critical times, it provides no benefit to the user. And just as real bodies are much less well-formed than beautiful statues, but they provide very many benefits in getting things done, so is the speech which is spoken from the mind on the spur of the moment ensouled and living, and it keeps up with events and is like those real bodies. But the written speech has a nature which is like a mere image of a real speech and is devoid of all active force.

Premeditation and planning supposedly lead to guaranteed ekplexis here, but at the expense of the ability of one's argument to move around of its own accord and adapt to the current situation: precisely what Socrates describes in the Phaedrus. There is a deeper dichotomy implied by Alcidamas' words here - that

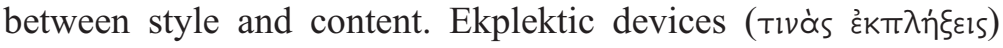
can be pre-prepared with a particular stunning effect in mind, he seems to be saying, but the sacrifice this entails is the loss of the ability to move around within an argument. ${ }^{23}$ Here again prewritten/pre-prepared speeches have become only imitations of 'real bodies' and are not themselves truly alive - though the implication is that such speeches might give such a marvellous and thrilling approximation of being alive that it becomes almost impossible, at least for the audience, to tell the difference. ${ }^{24}$

In Plato's view either becoming a producer of or falling prey to the thauma created by these astonishing pre-planned performances is a risky business. The comparisons of Charmides to an agalma and

23 See O'Sullivan (I992) 74-5 on the place of ekplexis in Alcidamas' work.

${ }^{24}$ Cf. McCoy (2009) 49-5I and Muir (200I) 62 on the contrast between living, moving speeches and inanimate text here. 
an actor are both parallel to and equally prescient of the eventual aporetic outcome of the dialogue, and even the eventual disastrous outcome of Charmides' life. Socrates' failure to have any real effect on the young man is particularly poignant given his continued association with Critias and their eventual violent ends. Both men lost their lives after involvement with the tumultuous regime of the Thirty: Critias as the notoriously violent leader and figurehead of the group and Charmides as a member of the Piraeus Ten. ${ }^{25}$ Within the setting of the dialogue, the young man's status as a wondrous object of eros and his inability to make much headway with his attempts to engage in philosophic thinking really matter: by the end of the dialogue, the failure of Socratic philosophy and the inability to resist certain types of thaumata are shown to have a terrible price.

\subsection{Thauma Idesthai: Wonder, Divine Artworks and the Ekphrastic Tradition}

In the Charmides, Theaetetus and numerous other dialogues Plato plays with the distinctly visual aspects of thaumata and compares and contrasts these objects of the phenomenal world with the thaumata of philosophical reasoning, which are not visible at all. Why does Plato return to the lure of this type of wonder so frequently in his dialogues? And why does he hit upon thauma as one of the most powerful (and potentially disturbing) effects of verbal and visual artworks alike?

To begin to answer this question, it is necessary to examine the connection between wonder and vision in Greek culture from the archaic period onwards. ${ }^{26}$ This connection is extremely strong. In

25 See Nails (2002) 90-4, I08-I3 on the involvement of Critias and Charmides with the actions of the Thirty. For recent discussions of the relevance of the later political careers of Charmides and Critias in relation to Plato's dialogue, see Danzig (20I3) 486-5I9 and (20I4) 507-24 and Flores (2018) I62-88.

26 Prier (I989) provides the best overview of the strong connections between thauma and vision in his phenomenological account of sight and appearance in Archaic Greek poetry; see also Hunzinger (1993), (2015) and (2018) on thauma and the visual from Homer onwards; cf. D'Angour (20II) I34, I48-50 on the connections between the concept of novelty and thauma, dazzling light, vision and responses to visual artworks in ancient Greek culture. 
early Greek hexameter poetry, sight is the sense most clearly linked to the marvellous. ${ }^{27}$ In Homer and Hesiod the formulaic phrase thauma idesthai ('a wonder to see') points to this, and it is primarily their impressive visual aspects that make phenomena explicitly labelled as thaumata induce wonder in their viewers in early hexameter poetry. For example, impressive weaponry or armour is often said to inspire wonder in its beholder, especially in the Iliad: such objects described in that poem as 'wonders to see' include the chariot with special gold, silver and bronze wheels prepared by Hera and Athene to aid the Achaeans (5.724-5), Rhesus' golden armour (I0.439-40), and Achilles' original armour, once given by the gods to his father Peleus (I8.82-4). Beautiful houses or palaces and their contents are described as similarly visually striking in both of the Homeric poems: Hephaestus' workshop, for example, dazzles Thetis with its marvellous self-propelled tripods at Iliad I 8.372-7, while Telemachus and his companions wonder at Menelaus' magnificent palace at Odyssey 4.43-4.

Other, more elaborate objects of craft elicit even greater wonder from their viewers. In longer passages of epic ekphrasis the

27 There are a few exceptions in early Greek hexameter poetry which designate sound or speech as a thauma, though in general the question of the relation of thauma to what is heard is explored much more intensely later in the Greek tradition. The exceptions which we do find in Archaic poetry include Telemachus' ever more daring speeches in the Odyssey, which increasingly astonish Penelope and the suitors as the narrative proceeds (see $O d$. I.38I-2: repeated at I 8.4IO-I I and 20.268-9). But it is not primarily the sound of Telemachus' speech or even the speech itself which causes the thauma in these cases, but the overall impression created by the rapid change in his behaviour. More ambiguous perhaps is the suitors' wondering response at $O d .4 .638-9$ to the report that Telemachus has dared to go to Pylos without their prior knowledge. In this case it is not only Telemachus' unexpected behaviour but the surprising nature of the report which has caused this awestruck response. This second example is very much the exception to the general rule that Homeric thauma, in terms of its sensory basis, is grounded primarily in the visual. An even more interesting example is Hes. Theog. 834, where the many voices and sounds which Typhon utters are said to be 'marvels to hear' ( $\left.\theta \alpha \cup \dot{\mu} \mu \alpha T^{\prime} \alpha^{\prime} \kappa o u ̃ \sigma \alpha l\right)$. Pindar picks up on this unusual Hesiodic passage in his own description of the wonder of Aetna (whose eruptions are actually caused by Typhon, who is imprisoned beneath the mountain) near the beginning of Pythian I, where he puts his own twist on what 'hearing' a marvel is by claiming that even hearing a report of Typhon's angry outbursts, rather than seeing him, or hearing the noises he makes, is

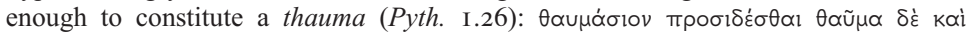

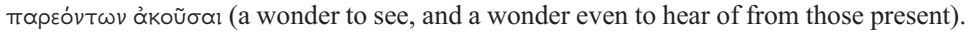
On the sense of 'ecphrastic wonderment' created at this moment in Pindar's ode, see Fearn (2017) I87-8; on the connection between Hes. Theog. 834 and Pind. Pyth. I.26, see Passmore (2018) 733-49. 
designation of a beautiful object of (often divine) material craft as a thauma idesthai becomes a topos of ekphrastic form from Homer onwards. ${ }^{28}$ The shield of Achilles in Iliad I 8 is the most important and obvious example. In fact, the creation of thauma is revealed to be one purpose of the construction of Achilles' new shield even before Hephaestus sets to work making it. The god tells Thetis that his aim is to ensure that future viewers will wonder at the object which he crafts, and this ability to cause future thauma is explicitly modelled as a consolation for the fact that he is unable to protect Achilles from his inevitable death (I8.462-7):

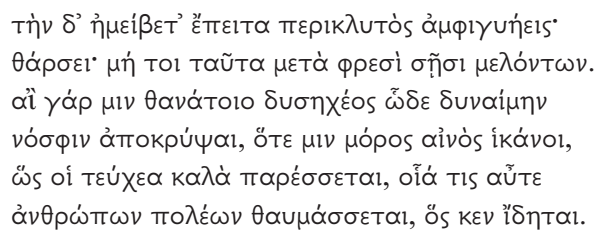

Then the famous lame god replied to her: 'Take heart, and do not let these things trouble your mind. If only I could hide him away far from screeching death, when dreadful fate reaches him, as surely as beautiful armour will be his, such that anyone among the multitude of men will marvel at it, whoever sees it.'

Achilles' possession of the ultimate object of divine craft comes to symbolise his liminal position between gods and men, a position which attracts a wondering response from others. Furthermore, the potential thauma which the shield will inspire in the future is parallel to the workings of kleos itself as a compensation for Achilles' mortality. As such, we here find the first hint that the ekphrastic passage to follow, and the thauma it both describes and causes, is in some sense analogous to the sense of wonder the listener putatively feels at hearing the accounts of heroic kleos

28 The best discussion of the importance of thauma as a reaction to ekphrasis and as a means for poets to make claims for the power of their own art remains that of Cunningham (2007) 65-6, who argues that thauma is '[ $t$ ] he prophetic word of the ekphrastic' and that the 'thaumaturgical force' surrounding the ekphrastic object is something that 'writing and writers want to share, and are in fact claiming by proxy, by analogy, by such intermedial intrusions into the text'. For other good recent discussions of the importance of thauma in ekphrasis, see e.g. Gutzwiller (2002) 96-7, Becker (I992) I2-I3, I8-I9 and (I995) 29-37, I IO, I29, Race (I988) 56-67 and Squire (20 I3) I $59-63$. 
enshrined within the Iliad itself. ${ }^{29}$ The scenes on the shield reinforce this idea. One of the main reasons for the guarantee of this future thauma is presumably the combination of movement and voice on Achilles' shield, which renders it a special wonder to look upon. In fact, the shield's depiction of the reaction of the young women who stand and marvel at the sight of men whirling about and dancing to the sound of flutes and lyres potentially models the ideal wondering response to the visual and verbal impact of both the described object and the ekphrasis itself (I 8.494-6):

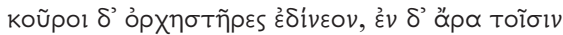

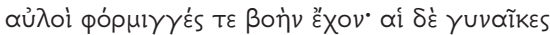

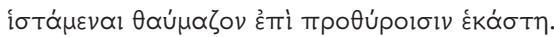

And the young dancing men were whirling around, and with them the flutes and the lyres blared, and each woman stood at her doorway and marvelled.

The later description of the shield even suggests that the depiction is so realistic and wondrous that the figures upon it seem almost to be alive, as the depiction of two forces clashing and fighting with figures who are like 'living mortals' makes clear (ळ̈s $\tau \varepsilon \zeta \omega \circ i$ Вротоi, I 8.539). The fact that the shield, a work of plastic art, somehow manages to involve movement and sound as well is one of the primary aspects of the wonder it inspires; it creates the impression that in some sense the work itself is a living and breathing object. The play between the animate and the inanimate, the static and the illusionistic impression of realism that this creates, is of the utmost importance, as the 'great marvel' of Hephaestus' depiction of a ploughed field emphasises ( I 8.548-9): 'And the earth behind was black and looked like it had been ploughed, even though it was made of gold: in this way the outstanding marvel was crafted' (í $\delta \dot{\varepsilon} \mu \varepsilon \lambda \alpha i v \varepsilon \tau^{\prime}$ ömı

29 For the view in antiquity that ekphrastic objects in some sense reflect the poet's own verbal craft cf. $\Sigma$ ad. Il. 3.I 26-7 on Helen's tapestry, which depicts the battles of Trojans

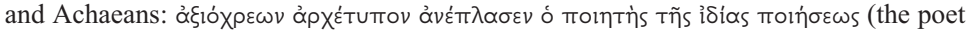
has fashioned a worthy model of his own craft). See Becker (I995) 55 on this comment. However, cf. also the note of caution regarding reading the Shield of Achilles as a direct analogue of the poet's art at Ford (I992) I68-9 and (2002) I I 5-I6. 


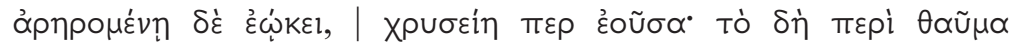
Tह́TUKTO).

The verbal depiction of movement and sound in a description of a seemingly static and voiceless work of visual art becomes the most crucial ingredient of the ekphrastic thauma of Achilles' shield. It also becomes an essential topos of the later ekphrastic tradition. The description of the shield of Heracles in the Hesiodic Scutum bears witness to the importance of such thaumatic elements in the later ekphrastic tradition. The shield described in the Hesiodic poem is explicitly designated a thauma idesthai (I40), with various specific details of its depiction singled out as especially worthy of wonder, such as fearsome burning snakes, which are labelled 'wondrous works' ( $\theta \alpha \cup \mu \alpha \tau \alpha \dot{\alpha} ~ ह ै \rho \gamma \alpha, ~ I 65)$, and the figure of Perseus floating off the ground, which becomes a 'great wonder

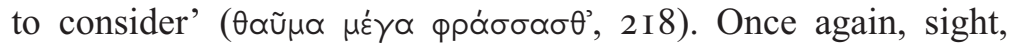
sound, movement and an uncanny lifelikeness are often combined on the shield: a depiction of deadly Fate 'glares terribly and

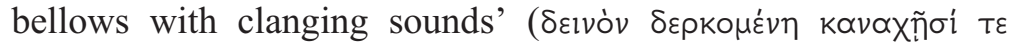
$\beta \varepsilon \beta \rho u x \cup i ̃ \alpha, I 60)$; when the Gorgons rush after Perseus 'the shield

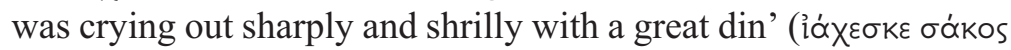

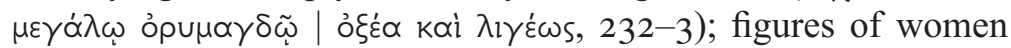
crying out and rending their cheeks 'resemble living women' ( $\zeta \omega \tilde{n} \sigma l v$ ik $k \lambda \propto l, 244)$. Certain other details present an especially hyperbolic rendering of the thaumatic features of the Iliadic shield (3 I4-20):

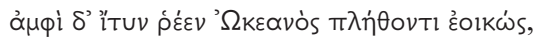

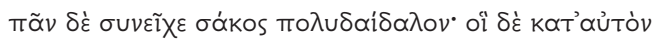

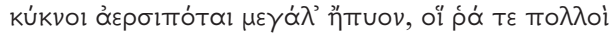

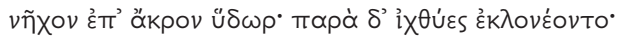

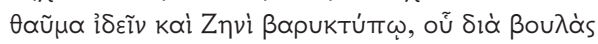

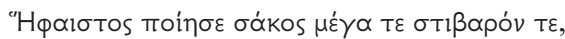

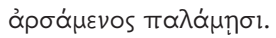

And around the rim Ocean was flowing as if in full flood, and it was surrounding the highly-wrought shield on all sides. And upon it were high-soaring swans calling loudly, and many were swimming on the water's surface. And beside them the fishes were being driven in confusion. It was a wonder to see even for deep-thundering Zeus, through whose designs Hephaestus made the great and sturdy shield, joining it together with his hands. 
While Achilles' shield will inspire wonder in any mortal who sees

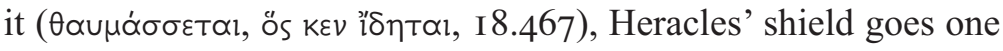
better: even Zeus, most powerful of all the gods, marvels at Hephaestus' wondrous craft in this instance. ${ }^{30}$ The Hesiodic Scutum is thus the first major example we have of a work which plays with the thaumatic topoi of ekphrasis initiated in the extant tradition by the description of Achilles' Iliadic shield.

Thauma remains an important element of ekphrastic descriptions of artworks and objects of craft in the ancient literary tradition. By the time we reach the Hellenistic period, the power of thauma within ekphrastic description is explored in increasingly sophisticated ways. The sense that the distinctions between the living products of nature and the products of human craft which imitate those natural beings are collapsing is particularly prevalent. A new emphasis on the capability of the artwork to speak and move as if it were alive is yoked to a parallel amplification of the sense that the thauma of the work of visual art being described also applies to the poet's verbal art. Furthermore, the invented object of the poetic description often points, even more emphatically than Homer's shield, to the poem itself.

This is certainly the case in the ekphrasis of the goatherd's cup in Theocritus' first $I d y l l$, where we find a much more explicit connection between the parallel processes of visual, verbal and textual artmaking. Thauma is referred to most directly when Theocritus, in his most forceful gesture of this kind in the poem, directs our response towards the cup-as-poetry at the end of the ekphrasis, when the acanthus curling round the cup is described as 'a wonder of the world of the goatherd: a marvel to astonish your

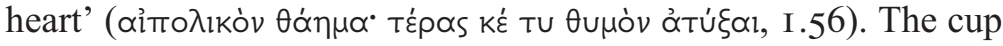
itself is offered in exchange for song within the narrative of the Idyll: Thyrsis' song - and by extension, Theocritus' own bucolic song - is therefore held up as inspiring a similar sense of thauma as the cup. Moreover, thauma has already been hinted at in the beginning of the ekphrasis, through the choice of the Homeric

${ }^{30}$ For a discussion of other passages in the Scutum which make similarly hyperbolic use of references to sound, spectacular sights, colour and movement in comparison to the concomitant descriptions of similar elements on the Iliadic shield, see Martin (2005) I58-60. 
Hymn to Dionysus as the model for the description of the ivy tendrils that surround the cup (I.29-3I):

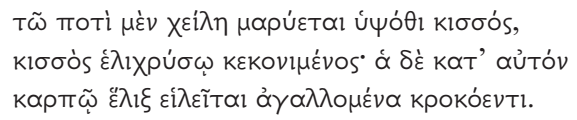

High up on the lip winds ivy, ivy sprinkled with helichryse, and along it curls round the ivy tendril exulting in its yellow fruit.

Gutzwiller has correctly pointed out that the description of the ivy which entwines itself around the mast of the ship in the following passage of the Homeric Hymn (38-4I) forms the background to Theocritus' version here:

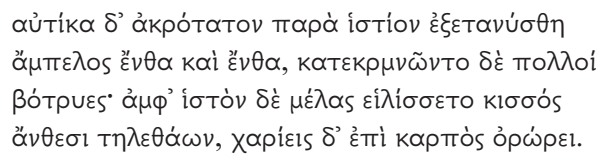

Now along the topmost part of the sail a vine spread out this side and that, and many clusters of grapes hung from it. Ivy was circling around the dark mast, blooming with flowers, and lovely fruit grew on it.

The rapid and spontaneous appearance of ivy winding its way over the ship is one of a series of 'wondrous deeds' ( $\theta \alpha u \mu \alpha T \alpha$ हैp $\gamma \alpha, 34)$ through which Dionysus manifests himself to the pirates on board the ship in the Hymn: the point of this echo is to imbue the Theocritean cup with the same sort of wondrous feeling as the description of Dionysus' series of epiphanic thaumata in that poem. Gutzwiller describes this perfectly: '[w] hat Theocritus has done here is to recast a miracle, which was acceptable under the terms of archaic religious thought, into a description of an object of art, marvelous in that its motion suggests either supreme artistic workmanship or the naïve imagination of the goatherd'. ${ }^{\text {I }}$ Moreover, Theocritus' own careful use of language in this description demonstrates the way in which striving for mimetically realistic effects in order to produce thauma is an aim of his own art as well. For example, the complex word order in these lines reflects

${ }^{31}$ Gutzwiller (I986) 254. See also Hunter ( I999) 78 on the way in which 'one Dionysiac miracle prompting amazement ( $h$. Dion. 37 ) is used to describe another' in this passage. 
the intertwined nature of the plants described, with the mimetic potential of the text on the page activating yet another source of thauma for the reader as Theocritus creates a visual representation of the artefact he is describing through words. ${ }^{32}$ This kind of play with the look of the written text on the page reminds us of other Hellenistic innovations which perhaps aim at a similar sort of thauma: the so-called 'pattern-poems' (technopaignia), and the increasing use of acrostics in verse of the period. ${ }^{33}$

The Milan Papyrus epigrams of Posidippus provide further examples of the significant role thauma comes to play in the increasingly complex relationship between verbal, visual and written artworks in the Hellenistic period. The language of thauma takes on a programmatic significance in the descriptions of wondrous engraved stones which open the collection. In this section, labelled Lithika, the precious stones which are described become objects of amazement through their combination of wondrous natural properties and skilful applications of human craft. Moreover, Posidippus' ability to transform conventionally prosaic or technical material on stones into aesthetically pleasing epigrammatic texts becomes a thauma in itself. ${ }^{34}$ But unlike contemporary prose technical treatises on stones, such as those of Theophrastus, the ekphrastic descriptions of gems in Posidippus' epigrams do not aim at elucidating the causes or context of these naturally occurring thaumata. Instead the aim of these epigrams, as Krevans astutely points out, is to provoke "not the satisfied "aha!" of understanding, but the round-eyed "oh!" of wonder'. ${ }^{35}$ This 'aesthetic of wonder' is created primarily by the speaker's focus on the combination of the naturally wondrous properties of stones and the marvellous human skill (techne) involved in

$3^{2}$ See Hunter (I999) 78 on the mimetic qualities of the word order reflecting the movement of the plants in this passage.

33 See Luz (20IO) for an overview of the use of technopaignia and acrostics in this period.

34 On the strong links between the contents of the Milan Papyrus and contemporary prose treatises, see Krevans (2005) 88. See also M. Smith (2004) Io9 for the idea that in the Lithika Posidippus reworks the scientific prose of Theophrastus' writings on stones in the same way as a real-life craftsman works up gems into beautiful aesthetic objects.

35 See Krevans (2005) 9I; cf. Krevans (20II) I26: 'In paradoxography, science is converted into ecphrasis: stop, look, and wonder'. See Bing (2005) I34 and Krevans (2005) 89-92 on the similarities in thematic content between Posidippus' Lithika and contemporary paradoxographical collections. See M. Smith (2004) I05 and Elsner (2014) I59-62 for a more general discussion of the repeated use of the language of thauma in the Lithika. 


\title{
2.4 Thauma Idesthai: Wonder and the Ekphrastic Tradition
}

gem carving. Three closely connected epigrams (I3, I5 and I7 AB) make the focus on this particular combination of natural and manmade thauma very explicit:

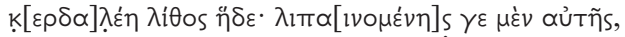

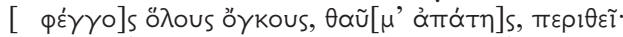

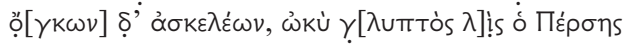

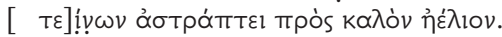

This is a crafty stone. When oiled a light runs around its entire mass, a wonder of deception. But when the mass is dry, straightaway the carved Persian lion flashes forth, extending himself towards the beautiful sun.

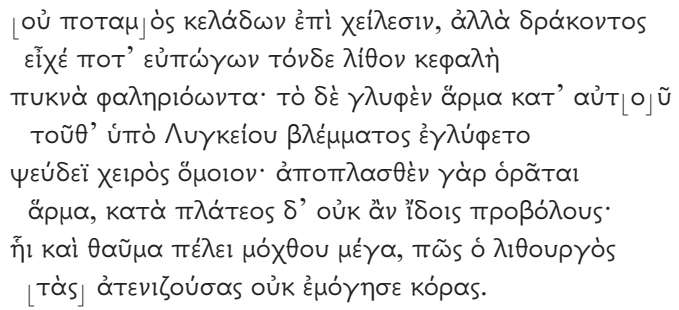

Not a river sounding upon its banks, but the well-bearded head of a snake once held this stone, thickly crested with foam. The carved chariot upon it, like a white mark on a fingernail, ${ }^{36}$ was carved by the eyesight of Lynceus. For a chariot is seen to be formed there, but on the surface you cannot see anything that projects out. This is the great wonder of his toil, how the stone-cutter did not damage his eyes while looking intently.

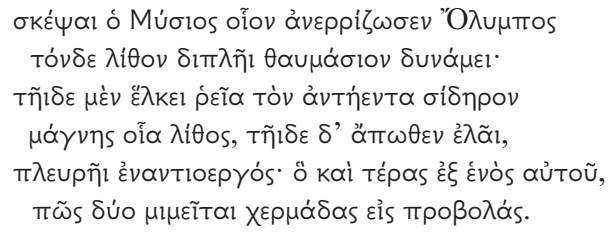

Look hard at what Mysian Olympus has uprooted: this stone marvellous because of its double power. On the one side it attracts the iron pitted against it easily, like a magnet. But on the other side it thrusts away causing the opposite effect. And the marvel is how one stone on its own imitates two stones with its impulses. ${ }^{37}$

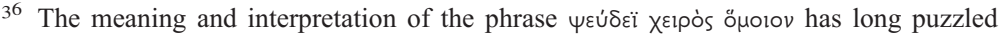
scholars: see Gow (I954) I 98 and Gow and Page (I965) 500-I for the suggestion that this phrase refers to white marks on fingernails.

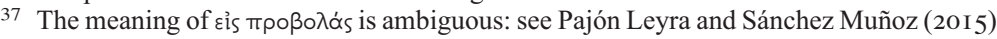
$3^{2-3}$ on possible interpretations of this phrase. 
In the first epigram (I3) the combination of human and natural thauma is emphasised - the stone has a naturally astonishing lustre when oiled, though its effect is made all the more marvellous when the Persian lion added by the human engraver is spotted when the stone is dry. The special abilities of either man or nature to make stones something to wonder at are then examined in turn. In epigram I5, the stone itself is not said to have any particular exceptional qualities, but it soon becomes something to marvel at due to the craftsman Lynceus' labour. In epigram I7, the magnetic stone described needs no human helping hand to become doubly wondrous because of its already inherently paradoxical qualities. In each case, Posidippus' ability to transform the dry scholarly material of the Peripatetic school on the subject of stones into a series of intricate and interconnected textual 'gems' is surely intended to provoke a concomitant sense of double wonder at his own skill as a writer. What makes the Milan Papyrus particularly interesting is the fact that here a new element has been introduced into the already conventional ekphrastic contest between the verbal and the visual: there is no longer a simple implied contest between verbal and plastic skill, but a new entanglement between the visual, verbal and textual works of human artists. Posidippus' achievement in creating an artwork out of the seemingly intractable material provided by previous technical and scientific prose literature turns the text itself into the ultimate object of aesthetic craft, something which naturally causes thauma in the reader. We are beginning to get a sense that in the world of the book, the sculpting of radically different texts and genres out of the raw material of the literary tradition has now become one of the most wondrous crafts of all. It is this process which lies at the heart of the aesthetics of the Hellenistic paradoxographer, as the next chapter will demonstrate.

When viewed from this angle it becomes easier to understand why a writer working in an excerpting and miscellanistic mode can, contrary to modern value judgements about the aesthetic quality of such texts, come to be seen as an extremely accomplished and wonder-inducing artist in their own right. In the Hellenistic period it is the paradoxographer who takes this search for artistic thauma to its logical extreme and produces marvels of 
2.4 Thauma Idesthai: Wonder and the Ekphrastic Tradition

his own through the deft and surprising manipulation of preexisting writings to form the textual marvel-collection. The emergence of paradoxographical collections therefore need not be viewed as a strange, unmotivated and pointless aberration, but as a cultural manifestation of the tendency to strive towards the production of artistic works which aim at arousing thauma first and foremost. It is this production of such textual thaumata that the next chapter examines. 